\title{
The Politicisation of Government Administration: The Limited "Brutal" Options of the South African Government Administration
}

\author{
MP Sebola \\ Department of Public Administration, University of Limpopo, South Africa \\ Email.Mokoko.sebola@ul.ac.za
}

\author{
Doi:10.5901/mjss.2014.v5n7p208
}

\begin{abstract}
The purpose of this article is to evaluate and analyse the politicization of the government administration in the South African context. This article challenges the view held by many scholars and practitioners of public administration and the public at large that there are available options dividing the politics and the administration of government, and that such is achievable in South Africa. In Africa and worldwide the citizens complain and associate the benefits of a government administration to be exclusive to a certain sector of individuals and their groups with sound political connections and inter-relationships. While today most government administrations claim to operate through systems that are fair, equitable and transparent, such claim remains relative because fairness, equity and transparency may only be a privilege to those within the circle of political friendship and ties in government. In essence, the general view held on the relationship between politics and government administration is that, there are alternative approachesto provide government administration that is neutral and objective to the politics ofthe country. The research question to be answered in this article is whether the South African government may have sound alternative approaches towards separating their government administration from their subjective party political agenda. This article argues, however, that South Africa's claim of fair, equitable and objectively practised public administration free from political persecution of the opposition is a myth which started with the Mandela's reconciliatory public administration through the Mbeki's depoliticized bureaucracy and the current politicized bureaucracy of the Zuma administration. A fair public administration free from political interferences and interventions is likely not to exist even in the most highly respected democratic states of the globe.
\end{abstract}

\section{Introduction}

The relationship between the administration of government and the political authorities remain a serious challenge in modern government administration. The government administration function is to implement policies to the satisfaction of the ruling party which has set both the developmental and political agenda of the country. The implementation of such policies shall mean implementation of policies by public officials belonging to different political ideologies to the members of the public belonging to the same as above. The challenge facing the ruling governments is having implementers who cannot be loyal to such policies or thinking to the opposite direction about the policies they have to implement. That often makes the ruling party to have limited options of operating in a multiparty democracy, and therefore, finally ends up politicising the employment appointment in their senior administration positions, often at the expense of effective delivery of services to the citizens. It is argued that at the lowest level of public administration such practice may not be considered significant. The implementers of such strategy are not worried about the individual capacity to deliver services to the public. That may compromise the ability of the governments' officials to provide a fair professional administration. This article argues that the politicized bureaucracyis simple and a lot more feasible than the complex dichotomy model which theoretically claims to separate government administration from the politics of the ruling party. The argument is based on the notion that most African governments claiming to apply the dichotomy model are, to a greater extent, practising a highly politicized bureaucracy than those not claiming it. The simple and less complex politicized bureaucracy option does,however, often compromise the capabilities of politically inactive public servants and discourages unity of the same citizens. Thus far, the ability of government administrations to serve all citizens with integrity and honesty without compromising their political agenda remains a wishful dream. South Africa's three phases of post apartheid government was seen going back and forth on adopting a convincing stand of ensuring political neutrality in government administration. Hence, the question of politicized or depoliticized public administration remains a critical area of debate in modern government administration. 


\section{Public Adminstration and Politics}

Mfene (2009:211), views public administration as a type of administration that is concerned with the execution of the rules, laws and regulations of the government of the country, that is, the execution of public services geared towards meeting the needs of the citizens (see also Botes, Brynard, Fourie, and Roux, 1996:257; Bingham, 1991: 02; Hanekom and Thornhill, 1993:57; and Tshikwatamba, 2007:761). This context implies the role of both the government of the day, and the appointed officials in executing services to benefit the country's citizens. Bayat and Meyer (1994:4) argue that the success of the government administration is mostly dependent on the policy it formulates and adopts, as well as the effectiveness within which those policies are put into practice. The translation of policies from an ideal state, to a real one has always been a difficult task affecting both the executive authorities and the public officials in the South African context.These have been attested to by the well-known study by Pressman and Wildavsky (1973) that policy implementation involves multiple stakeholders who adopt various decision paths. Throughout that process, the stakeholders are engaged in various contexts which in themselves encroach on the objectivity of the real policy objective.The increasing number of decision paths increases the number of decision makers; and decision makers in one path may not necessarily care about the outcome of the other path.

The question of the interrelationship between politics and administration has a long history of debate and is significant to the argument raised in this article. OZ Politics (2009:1) indicated that the business of administering and policing the laws made by parliament is far too big a job for the government ministers to do alone. Ministers are assisted in their executive role by the public service which comprises public servants employed in the government and associated agencies. This being the basic foundation of public administration in terms of the doctrine of "trias politicas" principle implies a solid relationship between political administration and the professional administration of such activity by the public officials. Any relationship in this context shall mean a little of trust and faith between the two institutions. The politicians and the public officials are, therefore, to be viewed as two sides of the same coin in achieving the demands of the country's citizens. The distinctiveness of their roles are often mentioned in government legislations; however, their roles have mutual implications.

While the business of politicians is clear, such as formulating policies and providing political leadership, Stanley (2000) listed the three distinct complementary functions of the public servant in government administration such as providing frank and fearless advice to ministers, helping ministers to promote, explain and defend government policies and implementing government policies. Those functions of course go with relevant competencies required for public servants to render such functions. Mafunisa (2003:90) argued that while it is critical for both the elected officials (politicians) and the public servants to appreciate their separation of powers in the real world, the distinction between the two is blurred. The demarcation between the two processes remains difficult to identify. As Svara (2001:3) puts it "... there is continuity between the political and administrative spheres, not a separation of the two, except as it applies to insulating administrative staff from partisan political interference".

\section{Separating Public Administration from Politics}

The separation of public administration from politics has been a subject of debate for over a century now. Up to so far there is no a legitimate claim that could be made by either public administration practitioners and scholars, that the debate is over and that an objective public service exists in government where both members of the right, leftist and center politics can be equally treated as loyal to the ruling government. Woodrow Wilson's ideas published in the Political Science Quarterly in 1887, in which one of his strong proposition was the separation of government administration from politics materialised to a certain extent.Woodrow Wilson's reliance on the exclusivity of politics and administration, the indivisible administrator and objectivity of law was based on the positivist dogma of the time that facts must be separated from values (Overman, 1996: 487; Dobuzinskis, 1997: 300). The scientific revolution at the time was aspiring to come out with the best way of doing the job informed by Scientific Management and the Weberian bureaucracy of objective division of labour and specialisation, raising hopes that indeed politics can be separated from administration (Morcol and Wachhaus, 2009:46). That rational bureaucratic image of specialisation is stuck in a discourse of public administration with the Newtonian linear conception to the extent that the shadow space of blurring relationship between politics and public administration is often taken for granted or go unnoticed. Maybe Woodrow Wilson was arguing from the context that politicians were professionals within their field of politics, which is not the case in the contemporary world of politics in Africa. Woodrow Wilson's opinion on that score has been held for at least two generations of public administration until questioned by the third generation. Thornhill (2006:796), however, indicated that the opinion of the third generation in which public administration cannot be dissociated from politics was only sustained for a short period due to the political 
scandals associated with the combination of the two. It can, therefore, be argued that despite the back and forth practices of the separation between party politics and public administration it continues to beimpossible to separate the two in the real public administration practice. It should be accepted as both a governmental management problem and a political risk to those thinking in the opposite political direction to expect a fair treatment and positive attitudes from the ruling elite. It should also be understood that the separation between the two exist in ideal situation and such arguments can only be sustained within the level of the academic environment only, and if the status quo remains, the future will question current teachings of public administration. It therefore becomes significant to look at the theories of the politics of public administration, the ideal versus the real political administration environment and the rationale for politicisation.

\subsection{The theory of the politicisation and depoliticisation of public administration}

There are basically five theories or models that underpin the discussion on the relationship between public administration and politics. These include the Dichotomy (depoliticized) Model, Politicised Bureaucracy Model, Complementarity Model, the British Permanent model and the American Hybrid Model. For the purpose and relevance of this article, only the Dichotomy and the Politicised Bureaucracy Models will be briefly analysed in the context of public administration and politics. The other three models are also engaging their principle from the content of the two. The Dichotomy model holds the view that the interference by the politicians in public administration is inappropriate and will erode administrative efficiency and temper with the administrative neutrality of public officials. The model maintains that there is a complete separation of the responsibility between politicians and public officials. This model is opposed to the Politicised Bureaucracy Model which suggests that public administration and politics are one unit in which party structures dominate decisions in administrative matters (Mafunisa, 2003:88). The application of this kind of model implies that the rewards and appointment in public administration should be based on blind loyalty to the ruling party. Thus far the relationship between the public office bearers and political office bearers in the South African context remain blurred. It is difficult to differentiate the distinct line of responsibility between the two institutions. Maphunye (2001:316-317) indicated that South African public official and political office bearers acknowledged the overlapping of their functions, that also revealed their frustrations regarding failure to put each other's function within an acceptable political and administrative system. The practical realities in public administration practice is the politicisation, while the depoliticisation remain an existing legal practice which is partially implemented with conscience and mistrust of the members labeled as opposition.

\subsection{The ideal versus the real political administration environment}

In an ideal situation, public administration is seen as an objective institution with clear distinct activities separated from politics. In the real political and public administration environment, the people are expected to accept the situation and only develop measures and ideas of managing the political realities. Most citizens believe in an ideal situation where they think that public administration can take place within an objective environment in which the public service can be an apolitical structure serving the interests of citizens equally. Such a perception ended up being a pipedream.

In explaining the unexpected in political realities of government administration, a Senior ANC politician in the Limpopo Provincial legislature said,

"Electoral power is about controlling the state, if a party wins the elections, it must run the government. I don't understand people who want us to take off our hands from the government, when the ANC is the strategic centre" (City Press).

The fact as to whether the government in power promotes political or apolitical approach in administration is immaterial. The significant aspect to be answered is whether the politics of such administration are fairly handled to minimise the conflict that can arise among citizens of the same country. OZ Politics (2009:4) indicated that the greatest concern about ministers from political parties has been about the loyalty and responsiveness of the public service to government policy. The politicians will normally prefer to be served by people who may be believed to be loyal to the party political ideologies and policies. Mentz, Kellermann and Kotze (1990:18-19) argue that the political neutrality of the public servants is an ideal type as the distinction between bureaucrats and politicians is blurred and the boundaries of separating the state, government, political party and the bureaucrats remain difficult. The moment one fails to determine the boundary, it becomes impossible to objectively define the separation. 


\subsection{The rationale for the politicisation}

Mafunisa (2004:85) indicated that politicised bureaucracy is significant in public service in instances where there is a greater perception of political sabotage by the incumbents of the previous administration. As such, politicised bureaucracy can be a justified manner in which a comfortable and secured zone is insured for the ruling elite. It can also be thought of as a logical reasoning for the ruling political party not to consider in their strategic appointments, people of the opposite political thought. This, however, has never proved to be a politically correct move all the time. But public administration itself is an eclectic area of activity that involves various strands of professional disciplines. Such professional state might not have space in terms of the politicisation of the bureaucracy. For example, a medical practitioner who is a superintended within the Department of Health needs no political alliance to ensure that proper clinical health policy is ensured within the department as well as the legal advisor who is a qualified legal expert. History has proved that in more than many instances public servants of various political ideologies have served the state professionally. Professor Harry Nengwenkhulu, an AZAPO bred politician positively transformed the Department of Education in Limpopo Province, and was later transferred to the EasternCape Province on a similar assignment. He is said to have maintained an apolitical approach in dealing with administration matters to the extent that even the provincial government had to compromise their political cadres to give him enough space to provide a fair professional administration in the Department of Education. It is not clear as to whether the incumbent's professional level of qualifications has played a role in this regard as it is distinct from deploying an ordinary person with a good political profile but lacking a professional competence required for the job.

As Gladden (1966:18-20) noted, the administrative function of a government should strictly be subservient to the political, to the service of whose ministrants it is securely dedicated, and that such administrators should implement programmes decided at the political level. In circumstances where administrators claiming technical expertise may exceed their proper function, they become power grasping bureaucrats and that opens loopholes for weak government and undemocratic situations. OZ Politics (2009:2) on the other hand recognises that there is tension between the service of a public servant and his personal ideologies as he has to marshal the arguments for or against a particular policy of the minister which he or she does not necessarily believe in. That in itself dictates the need for professional ethic in the field of public administration. Such professional ethic is informed by the discipline which implants the relevant competencies required in public administration.

Until today it remains a critical question as to whether the public service needs to be politicised or depoliticised. In the South African context, the politicisation of government administration was never publicly pronounced. It simmers within the practice of public administration to the extent where it becomes phenomenal in practice. At least in the two administrations of both Nelson Mandela and Thabo Mbeki, the South African citizens, irrespective of their political affiliations, may have suffered silent political isolation in strategic positions, and such was never publicly backed by political statements as it might appear in the era of the Zuma administration.

Mafunisa (2003:85) does, however, argue in favour of the politicisation of the public service which may result from perceived threat and political sabotage by the beneficiaries of the previous administration, and such politicisation should immediately cease to exist as the perceived threat and political sabotages are over. In this instance, it is not clear as to where the space of professionalism will be in the public administration principle. This may imply that in South Africa either the Mandela or the Thabo Mbeki administration may have been justified in politicising their administration so as to deal with the previous white minority beneficiaries of the previous administration. The question also arises of when the perceived threats and sabotage are over remains difficult to be determined. In South Africa the perceived threat of sabotage by the loyalists of the previous presidents become a problem resulting in a political division of the same members of the ruling clan.

\section{The Previous South African Public Service and Politics}

Like in other countries such as Australia, Canada and the USA, the South African public service has a long history of politicisation. The nationalist government in South Africa has always ensured that only members loyal to policies of their party were deployed at all strategic positions of the public service.Although this was aggravated by the racist apartheid policies of the nationalist government, this was the norm. According to Mafunisa (2003:93) the officials deployed were those who understood and were loyal to the party's policy of discrimination on the basis of race, ethnicity, language and sex. Such politicisation practices of the previous administration created a wide gap of disparities between various racial, ethnic and gender. As articulated by Mentz, Kellerman and Kotze (1991), it was difficult to differentiate the national party, the state, its politicians and the bureaucrats. Such politicisation was said to be an exclusive practice in which the 
resources of the country were said to be concentrated into the hands of the white minority class at the expense of the blacks and other racial groups.In essence, the apartheid public administration was not professional, unlike the current public administration which is principled in terms of the Constitution. That was to bring a serious challenge to the upcoming administration with regard to the maintenance of either the politicised or depoliticised public service.

\section{Post 1994 South African Public Service and the "Brutal" Politics}

Post 1994 government administration accumulated credibility of political support by promising the South Africans a fair administrative system based on the principles governing public administration as provided for in section 195 of the Constitution of the Republic of South Africa of 1996. Those principles are based on a number of normative requirements developed over the years in public administration (Van der Waldt and Helmbold, 1995:8). Normative guidelines are value norms worth striving for, which must serve as criteria for public conduct (Botes et al, 1996:285). These guidelines or norms underwent adjustments which eventually crystallised into a number of basic, identifiable ethical or moral behavioural guidelines (Van der Waldt and Helmbold, 1995:8). The Public Service is to operate from the premise of equality in which all races, ethnicity and physical abilities will be representative of the South African populations without compromising the citizens' capability. Such promise as articulated in the Constitution and other legislations meant the adoption of policies that will mutually achieve fairly exclusive ends for every South African. The difficult question to be answered in this manner was whether such mutually exclusive ends for everyone can be achieved through a politicised bureaucracy or through a depoliticised bureaucracy. While depoliticised bureaucracies sound like a fair administrative route for a sensible democratic government, a difficult question is whether it can provide security for the ruling elite against both political and administrative sabotage. While politicised bureaucracy may seem to provide security and comfort zone for the ruling party elite, how it promotes democracy and become relevant to the modern political administration system, is difficult to pronounce. Donaghy (2009:2) argues that politicised bureaucracy is insignificant in the sense that it undermines the practice of "frank and fearless" advice that could be given to ministers, and it also eradicates all forms of dialogue and the development of differing perspectives on policy issues. It can be further attested that it also undermines the profession of public administration that is founded on defined ethical norms and values.

Since the politicised bureaucracy may link well with unpopular public service administration practices characterised by autocracy and a system that may promote party patronage and corruption, the option did not really suit the South African post 1994 government. Even though the post 1994 South African government promised its citizens a fair administrative system representative of the South African society, the practical realities proved such a political claim otherwise.

\subsection{The system of "brutal politics"}

The "brutal politics" in the context of this article refers to a situation by which a major political party (ruling) in the country adopts a strategic move in which threatening political opposition are ironically treated as friends and colleagues while in reality a "brutal"political strategy is adopted and put into place by the same party to ensure a gradual permanent death of the opposition political parties from the political stage. Such strategy existed in most new democratic governments in which the potential emerging opposition parties had their elected politicians awarded ministerial posts by the ruling party with the intention of making them lose their political focus and mandate. South Africa is currently failing to be an exceptional in the application of such practice. South African public administration gave its people a hope of acknowledgement of the diverse society with diverse needs and interests. That created the picture that all South Africans shall enjoy the privilege, the rights and services from their government without fear of reciprocation or political persecution, and that a professional and competent administrative bureaucracy will be put in place. The realities throughout the post 1994 administrative interfaces indicated a notable political administration system in the country, which never ceased to show its citizens that the ruling government has only limited options of practising a just public administration, with only limited option of choosing a brutal political approach so as to manage the country's political affairs better.It should, however, be understood that from the onset, the ruling party (ANC) preferred a depolititicised bureaucracy. It is, however, not known whether such opinion was shared by the majority of the members of the ruling party. Influential senior ANC leaders such as Jeremy Cronin, then an ANC MP in 1994 and Cyril Ramaphosa, then ANC Secretary -General then, stated that they represented a constituency in the ANC that preferred the British Labour Party route (Venter, 2001:74). This is a route that maintains that government activities should be separated from party politics through utilisation of neutral professionals to stir the administration of the country.It is argued that such preference by the ruling party to rule without Lithuli House (their political house) was criticised by those in the Lithuli House accusing those 
in government of acting without a mandate from the strategic policy centre. Despite that, the ANC as a strategic centre of policy-making doubted the political neutrality of formal democratic institutions such as parliament, the constitutional court, provincial parliaments, the public service and various executive commissions (Venter, 2001:75). Taking into consideration the Cadre Deployment Strategy adopted by the ruling party in 1997, it became clear that the approach of depoliticised bureaucracy was nullified. Even if it emphasises to recruit politically and professionally equipped comrades that it is likely to be a wishful dream, as South African politics were always achieved at the expense of educational acquisitions. This article therefore analysis the three faces of limited brutal political options available to the South African government starting from the eras of Mandela, Mbeki and the Zuma era. It is notable that in each of these eras, it has been difficult for each of the leader to objectively avoid the notion of political supremacy that seemed to have disadvantaged the opposition.

\subsection{Mandela's reconciliatory public administration (1994-1999)}

Mandela's administration in South Africa represented an era of transformation and reconciliation of the separated South African societies. Barber \&Vickers (2001:339) refer to his ascension to the South African presidency as that one of a symbol of tolerance and political miracle of South Africa. This was also informed by the manifesto of the time being the Reconstruction and Development Programme (RDP) and the executive platform of having two deputy presidents being Mbeki and De Klerk. The Reconstruction and Development Programme (RDP) was the major policy initiative of the ANC government after the 1994 elections. It was an integrated, coherentsocio-economic programme. It attempted to integrate development, reconstruction, redistribution and reconciliation into a unified programme. It was intended to be a visionfor the fundamental transformation of South African society (RDP White Paper, 1994:7). Although such era looked reconciliatory at face value, some white critics' of the new era such as Gildenhuys (1997) viewed the era as the first era of "brutal politics" in South Africa. This is said to have been notable in the appointment of the white South Africans as a reconciliatory gesture. As Geldenhuys (1997: 108) argued against it, he pointed out that such a period was one in which white Afrikaans speaking South Africans were replaced by white English speaking South Africans. The period may as well not be regarded as a true period of reconciliation thought of in the public domain, especially from the Afrikaner community in the country. General George Fivaz, was appointed the first post- apartheid Commissioner of the Police Services in South Africa.He viewed his appointment as a positive political gesture and in one of his addresses he said "party-political interferences in policing should never again be tolerated as it has rendered many policemen unable to distinguish between legal and illegal orders" (SAPA, 1996:1). Despite rumours that such appointment was a transitional measure to gain confidence from both the public and the opposition, the Afrikaners in hidden corners spoke of his Swedish origin. Other symbols of good political gesture were seen with the offering of a second-deputy president post to De Klerk as the leader of the opposition National Party, and when Derek Kiss was appointed as governor of the Reserve Bank. All such appointments were short-lived as the incumbent were either voluntarily or compelled to go on public to declare other business interests which made it impossible for them to continue in such positions. Ironically, the press would mention that the President had listened to their concern and released them from their duties. Such an era may better be described as a period of gradual replacement of the transitional white liberalists by politically correct comrades. Whether this era is viewed as an era of reconciliation or not, the extent at which such reconciliation was achieved to a certain extent demonstrated the element of brutal politics of which there was limited option open to the ruling party leadership. Even Mandela himself did not retire with the satisfaction that his government served without experiencing political blames from what he calls the Afrikaner minority of Dutch-descended white settlers (Encylopaedia.Com, 2009:1). In his retirement speech he accused them of political sabotage in which they were trying to destabilise the country.

\subsection{Mbeki's depoliticised public administration (2000-2008)}

Mbeki's term of office was better described as one of service delivery and a nation that must get back to work (Venter, 2001:78). He is believed to have reorganised the President's Office into a "presidency", in which instance the presidency was situated in Pretoria and the Deputy-President acted on his assignments in parliament.In his administration South Africans were to be treated as citizens of the country rather than members of particular political groupings. His approach of a professional public administration which was to be free from political affiliation in senior government and political positions failed to do good to himself as a leader and to the opposition parties to whom he made those favours. His own constituencies accused him of having developed a highly centralised and technocratic response to the problems of governing exacerbating the problems of expectations, transparency and accountability in which he was perceived as distant, aloof and out of touch leader (Henwood, 2010:1). His non-political aligned public administration was seen in 
various forms of South African government administration systems, and had diverse consequences on himself and the other minor political parties. Firstly,his appointment of predominantly white members of the Scorpions on the basis of their ability derived from security experience gathered from dealing with ANC activists (himself not excluded) resulted in his downfall from the South African political stage. Secondly, his appointment of the two academically qualified politicians such as Mosibudi Mangena (AZAPO) and the less known Ntopile Kganyago (UDM) into ministerial posts gave the public an opinion of a professional public administration also replicating the reconciliatory gesture of the Mandela era (SADOCC, 2010:1). Ntopile Kganyago later died of a short illness (ANC Parliamentary Caucus, 2013:1, New Age, 2013:2 and Public Works, 2013:1) and was heavily praised for his role in South African politics though was not holding any senior political office anymore. Mosibudi Mangena is also rarely heard of in active South African politics. It is perceived from Mbeki's administration that little attention was paid on petty issues such as politically motivated appointments to public service offices. On various occasions and in public gatherings his administration sent strong warnings and promising punitive actions against those in government who would demand a party membership to offer positions to government officials. His premiers implemented the same principle which was acceptable to the majority of South Africans, but disapproved by the majority of the ruling party membership. More focus was on the rebuilding of the image of the country in the international context. His administration therefore was criticized of having created a vacuum of political leadership between the Luthuli house and the parliament.

Although his political administration may have represented depoliticised bureaucracy to a certain extent, it faced serious challenges and his political strategic response was therefore not immune from the definition of brutal politics from both the internal and external threats. The internal communists' threat was dealt with through active engagement in ANC politics and programmes of government to the extent that communists' redeployees completely forgot a communist mandate from their constituencies. He lost touch by sacking Zuma off his Deputy-President post in 2005 (Henwood, 2010:1) which also served as a signal of his adherence to the ethics in public administration. This has also helped the SACP to regain its lost influence by supporting Zuma who was believed to share a bit of socialist ideology.

The floor crossing bill which initially was a brain child of the Democratic Party (DP) and the New National Party (NNP) in 2001when they proposed to formalise their unification into the Democratic Alliance (DA) was rejected by the ANC because it was perceived to be an initiative of a congealing of a race and class based political opposition (Wikipedia, 2010:2). Within a year of such rejection, the NNP announced its desire to leave the DA and form alliances with the ANC and the floor crossing legislation was passed. The move which can be perceived as politically calculated by the President of South Africa was a complete signature of a death warrant of the NNP, thereby rewarding Van Schakwyk with a ministerial position. Between the periods 2003 and 2007, the ANC had gained 27 seats and lost zero seats through floor crossing, while other parties such as the DA gained 10 and lost 5 . The UDM lost 10 seats and gained zero seats. Hellen Zille argued that during the floor crossing window period in Cape Town, 87\% of the National Party councillors that crossed to the ANC were appointed to positions with better salary (Wikipedia, 2010:3). While other opposition political parties such as Mangosuthu Buthelezi, Bantu Holomisa and Kenneth Mesoe viewed the floor crossing as a move that aimed at destroying their emerging political parties, the then ANC Chairperson, Mosiiwa Lekota refered to it as a legislation adopted for "some political realignment... and the breakup of racial power blocks". During Mbeki's term of office as President of the Republic, the South Africans saw a period of acceptance in the public sector without political reciprocation, but on the other hand they experienced the death end of major political opposition parties.

To a certain extent his depoliticised bureaucracy was questioned by other critics of his government administration. Klatzow (2010) wrote that although he was thought of as Mr Delivery, he unfortunately turned out to be Mr Non-Delivery when his administration became ideology driven than ability driven, in which all functionaries in government were replaced by loyal party cadres. While the former assertion may be thought of as untrue, this may also get support from the people that removed him from power, because of believing that in his administration people outside his league even though they belonged to the same political party were sidelined. Generally, Mbeki's administration was characterised by more of neo-liberal flavour which fell out of favour from the alliance partners. Understandably, that since the era of Mandela's reconciliation various administrative processes which took place were more of public management conceit than public administration.

\subsection{The neo-liberal tendencies}

Mbeki's administration fell victim in the debate of other actors, like Congress for South African Trade Unions (COSATU) and South African Communist Party (SACP), in the macro-economic policy landscape in the country. His administration was said to be neo-liberal in the sense that he opted for a rationalised public service. The adoption of Reconstruction and Development Programme (RDP) after the 1994 democratic elections as well as the introduction of Growth, Employment 
and Redistribution (GEAR) policy during 1996, set the stage of debate and practice in public administration. In practice, public administration was set out to mediate between the social goals of the RDP and the economic imperatives of GEAR through the implementation of policies that were put in place. Aspects of efficient and effective public administration with a lean public service through rationalisation led to the unpopularity of Mbeki's administration, leaving the social partners dissatisfied as they saw government as a source of employment. The RDP promised jobs through extended community projects which were seen as a way of putting those who were aligned to the party to acquire jobs. Through the introduction a GEAR, the practice had to be changed to focus on efficient and effective strategies through apolitical public service, which would put South Africa in good stand of anticipated good governance, aspired in terms of major funders in the world. The ruling party's alliance partners' alignment to the Marxist theorisation of development, which is narrow on economic perspective, possesses a negative attitude in the sense that they stress the notion of underdevelopment (Leroke, 1996:224).

\subsection{Zuma's politicised bureaucracy (2009-?)}

Zuma's ascension to Presidency was through the support of people that had suffered or had made a legitimate or illegitimate claim of having suffered political isolation from the previous administration of President Thabo Mbeki. He therefore inherited a divided political party, which left him with the critical role of having to unite the three groups such as ANC groupings, the alliance and Mbeki allies, and also having to face the opposition of the breakaway faction of Cope (Friedman, 2010, 1). In his first address of the South African citizens, he spoke of his administration as that of a nation going back to work. That was of course the character of the Mbeki government. Unlike his predecessors, who came out clear on disclosing their depoliticised bureaucratic administration, his standpoint on that was not clear, but his followers did that successfully on his behalf. His appointments of people to strategic positions such as Safety and Security, Chief Justice, Defence and State Security displayed the highest level of a politicised bureaucracy as the appointment were given to those former political figures and friends who supported him against Mbeki (Talbot, 2009:2). Unlike his predecessor, who often was quite clear on matters that he did not believe in, his strategy of confusing his opponents was very clear on both the internal and the external opponents. In proving that, he gave them a platform to open debate about nationalisation, although that does not mean that he was promising them policy shifts of the ANC. Nationalisation has been debated extensively, but the status quo of the ANC policy on it remains intact. Under his leadership political contradictions are even worse. The capitalists ANC members are pushing for the nationalisation of mines, a view that contradicts the SACP viewpoint on the matter. Nationalisation should indeed be pushed by the SACP. But observations from the public are that such contradiction emanates from the fact that thus far, the ANC political heavy weights are monopolising, controlling and benefiting from government tenders, and a further extension to nationalised mines will close the benefits enjoyed by the SACP political heavy weights whose background and influence is in the mining industry.

While political brutality of the Mbeki era could have been practised in silence, in Zuma's era political opponents are worse as he has to deal with both the internal opposition loyal to the previous president and those in the alliance as well as the external threats from opposition parties. In that instance the external political opposition even became a less worrisome factor, but COPE employees in the government departments became a serious threat, especially because of their presumed link to Mbeki. Given the situation at hand, while political revenge and response against COPE members in the government administration became difficult to be hidden, the brutal political smiling with the opponents from political parties such as DA showed that there was a specific strategy in place. South Africans saw his government appointing, a right wing Afrikaner, Pieter Moulder of the Freedom Front Plus, to the post of Deputy Minister of Agriculture (Talbot, 2009:2). Tony Leon's appointment as an ambassador to Greece has been hailed by many as a good political gesture shown by Jacob Zuma to bring about unity among South Africans. As Williams (2010: 2) puts it, ambassadors are sent abroad to lie for their country, but Tony is a honest man who will not lie on behalf of the party, but will represent the country. Whether such was done as a good political gesture remains difficult to attest. What experience has shown is that opposition party members serving in the ruling party posts lose their political party mandate. By the time they come back to their constituencies and their political parties they have lost trust of their membership as it has been seen with small parties that diminished after joining the ruling party government.

\section{Is There a Future of Political Objectivity in the Zuma Administration?}

In a real public administration environment, the provision of political leadership in administration which is free from both political interferences and intervention is hardly existing. Therefore, the concerns by both laymen and academics about such interferences and interventions are to remain ordinary talks with little political impact. Svara (2001) in his article "The 
myth of the dichotomy model" concluded that the separation between the politics and the administration of government is but a theoretical affair. While the South African government may claim separation of the two, but the realities in the administration dictate that, like in all other countries worldwide they are likely not to tow the constitutional line as it is. In a country like South Africa, where unemployment rate is high, it is highly unlikely that the administrative system of the government may wish to benefit officials not loyal to their political party agenda. Even within the political agenda, there is an emergence of dissimilar ideas within the alliance of the ruling party and within the members themselves. The element of brutal politics in the country may therefore not only be limited to members of the opposition only, but also to members of the same political grouping belonging to a different clique within the organisation.

Thus far President Zuma's era of political leadership in South Africa is to be remembered as an era of both mild political brutality and contradictions. The society and political associations have not been able to see and predict his future political plans. However in his first term of office announced that he owes none of his political friends that supported him to oust his predecessor.But political loyalty was seen to be well rewarded to his allies through lucrative posts and ministerial posts (i.e. in Safety and Security, Chief Justice, Defence and State Security), while the former Mbeki allies experienced the worse brutal and political isolation either in public administration or in their political party agenda matters. The SABC board appointed by the former president was dissolved amid speculations that they may claim independence (Duncan, 2013) and provides air space to the former president and that would have threatened the credibility of the current ruling elite. Indeed the post Mbeki SABC board appointed by the latter made the former president to suffer political brutality in which instance his name on the SABC channels was mentioned only where he was to be blamed for a political mess of the country.

Political contradictions of Zuma's era never ceased to surprise both Africans and his allies. Julius Malema's surprising turn against him by pushing for nationalization brought about own political disaster- which proved to him that the practice of political brutality against comrades is not a one way road- but can also be practiced in reverse. Zwelinzima Vavi's opposition of the Zuma administration and his underestimation of the fact that his popularity by the working class did not make him indispensable landed him in a political embarrassment (Fogel, 2013:1-7) of which recovery from such is not positively predictable. Zuma's era of South African politics as captured by Pillay (2008) marked the beginning of a more reckless, intolerant and a neo-Stalinist type of politics. The COSATU Committee Report (2011:1-3) revealed his administration as the emergence of a powerful, corrupt, predatory elite combined with a populist agenda to harness the ANC to advance their own interest. And such as reflected in COSATU National Congress Report (2013:1-26) and Gentle (2013:13) predict the brewing of ingredients for cracks and crisis in the tripartite alliance. Thus far it is difficult to conclude that politics can follow a particular ethical approach. In his approach of government President Zuma has been an unpredictable political leader who on many occasion applied the political notion that there are no permanent friends in politics and to a larger extent opponents that underestimated his ability in political game have their political careers ending in a drastic manner. On 9 November 2012, he on his own delivered the Thabo Mbeki Centenary Lecture in the Eastern Cape (African National Congress, 2012:1-6). In the lecture Thabo Mbeki is portrayed as one of the most memorable selfless leader and the $11^{\text {th }}$ president of the ANC. It is not known if the lecture will delete the memoirs of being likened to a dead snake with a squashed head by the same presenter. It is not known whether the lecture was ending his internal political persecution. We like it or not those in political positions will always exercise some form of political brutality on opponents that seem to threaten their existence.

\section{Conclusion}

This article argued that the three eras of political transformation in South Africa were indeed characterised by a politicised public administration which has little patient for those not belonging to the ruling party. The article concluded that even if the Mandela and the Mbeki administration were hailed the best administration that gave South Africa a credible image worldwide, that did not immune their system of administration from the practice of a little brutal political strategy that aimed at diminishing the existence of those belonging to a different political thought. While many articles have been written about the politicisation and depoliticisation of the public service, however naming the best of the two systems has been difficult.

\section{References}

ANC Parliamentary Caucus. 2011. Death of UDM Deputy President Ntopile Kganyago. Available online: www.ANC.Polity.org. Accessed on 18/10/2013. 
Barber, J and B,Vickers 2001. South Africa's foreign policy. In Venter, A(ed). Government and politics in the new South Africa. Pretoria: J.L Van Schaick.

Bayat, M.S and I.H Meyer 1994. Public Administration and Management. Pretoria: JL Van Schaick Academic.

Botes, P.S., Brynard, P.A., Fourie D.J. and Roux, N.L. 1996.Public Administration and Management: A guide to Central, Regional and Municipal Administration and Management. Cape Town: Kagiso Publishers

COSATU, 2013. Political Report to the $5^{\text {th }}$ COSATU Central Committee. Pretoria: COSATU.

COSATU, 2013. Secreterial Report to the $11^{\text {th }}$ COSATU National Congress Political Report. Pretoria: COSATU.

Department of Public Works. 2013. Former Deputy Minister Ntopile Kganyago laid to rest. Government information: Pretoria.

Donaghy, T.D,.Death of the Australian Femocrat. University of South Australia: Hawke Research Institute.

Duncan, J. 2013. Lessons from the Demise of Thabo Mbeki. The South African Civil Society Information Service. Available on www.sacsis.org.za. Accessed on 18/10/2013.

Encylopedia.com, 1998: Mandela resigns as ANC leader; condemns whites attempts to sabotage government.(Also available on internet) www.encylopedia.com. Accessed on 20/10/2010

Fogel, B. 2013. South Africa: Pro-government faction attacks COSATU's Zwelinzima Vavi. International Journal of Socialist renewal. Available online: www.links.org. Accessed on 18/10/2013.

Friedman, S. 2010. 100 days, early days, but Zuma shows signs of presidential promise. University of Johannesburg: Center for the study of democracy.

Gentle, L. 2013. A week in August: Factions in COSATU, Economic Fear Mongering and the State we're in. The South African Civil Society Information Service. Available online: www.sacsis.org.za. Accessed on 18/10/2013.

Hanekom, S.X and Thornhill C. 1994.Public Administration in Contemporary Society: A South African Perspective. Revised Edition. Halfway House. Southern Book Publishers

Henwood, R 2010. Emerging trends in South African politics post-Mbeki. Department of Political Science: University of Pretoria website.

Mafunisa, M.J 2003. Separation of Politics from the South African Public Service: Rhetoric or Reality? Journal of Public Administration. 38 (2): 86-101.

Mfene, P.N 2009.A service delivery perspective on public administration. Journal of Public Administration. 4(1): 209

Mulgan, R,. Truth in Government and the Politicisation of Public Service advice. Australia: The Australian National University

Pressman, J. L. and Wildavsky, A. (1973). Implementation. Los Angeles: University of California Press, Ltd.

Pillay, D. 2008. COSATU, SACP the ANC post-Polokwane: Looking Left but does it feel ? Labour, Capital and Society, $41(2): 5-37$.

OZ Politics, 2009. The Public Service. Also available online: www.ozpolitics.org. Accessed on 7/2/2009.

SADOCC, 2004. Fervent Plea by Mandela/ Government completed. Also available on internet.www.sadocc.at/news/2004-159.shtml. Accessed on 21/10/2010.

SAPA, 1996. Fivaz say no to party-political interference in policing. Johannesburg: South African Press Association

Stanley, M. 2000. How to be a Civil Servant? United Kingdom: Politicos Publishers.

Svara, J.H. 2001. The myth of the dichotomy: complementarity of politics and administration in the past and future of public administration. Public Administration Review. 61(2): 176-183

Thornhill, C 2006. The domain of Public Administration. Journal of Public Administration. 41(4.1): 793- 806.

Thornhill, C. 2007. Research in Public Administration: Some South African developments. Administratio Publica, 15 (2): 1-18

Tshikwatamba, N.E. 2007. A critical and inter-disciplinary analysis of the selected criticisms leveled against Public Administration. Journal of Public Administration, 42 (8): Pages 33-43

Venter, A 2001. The Executive. In Venter, A (ed). Government and politics in South Africa. Pretoria: J.L Van Schaick.

Wikipedia, 2010.Floor crossing (South Africa).Also available online: www.wikipedia.org. Accessed on 2/10/2010.

Williams, M. 2010. Tony Leon, diplomat. The Citizen, 4 March 2010. Johannesburg: The citizen. 